\title{
KUAFÖRDE İNŞA EDİLEN GÜZELLİK SÖZLEŞMESİ: ANKARA ÖRNEĞİ
}

\author{
THE STRUCTURING BEAUTY CONTRACTS AT THE HAIRDRESSERS: \\ SAMPLE OF ANKARA
}

\section{Ercan GEÇGIIN**}

ÖZ: Nitel araştırma yöntemine dayalı gerçekleştirilen bu çalışma, Ankara'nın farklı semtlerinde seçilen kadın kuaförleri ile kuaförün müşterisi olan kadınlar üzerinedir. Araştırma; düşük, orta ve üst sosyo-ekonomik düzeylerine göre kadın müşterilerin kadınlık imajlarının kuaförlerde nasıl farklılaştığına odaklanmaktadır. Farklı semtlerde ikamet eden ve farklı sosyal pozisyonlara sahip 50 kadın ile 15 kuaför çalışanı ile derinlemesine görüşmeler gerçekleştirilmiş ve kuaförün kadınların dünyasındaki anlamı ve önemi sorgulanmak istenmiștir. Çalıșmada, kuaförlerin farklı sosyo-ekonomik düzeydeki kadınlar için imaj ve kimlik açısından giderek zaruri bir hizmete dönüştüğü ancak kuaför hizmeti alma biçiminin sınıfsal konumlara göre değișiklik gösterdiği keșfedilmiştir. Bulgular ıșığında kuaförler, kadınların kullanım amaçlarına ve ișlevlerine göre kategorize edilmeye çalışılmıştır. Sosyo-ekonomik açıdan daha alt düzeyde olan kadınlar kuaförleri evin uzantısı olarak kullanma eğiliminde iken daha üst düzeylerde kuaförün araçsal açıdan kullanma eğilimin arttığı gözlemlenmiştir. Araştırma sonucunda kuaförlerin kadınların hayatında çift yönlü işlevler gösterdiği açığa çıkartılmıştır. Kadınların imaj yapılandırılmasında, sosyalleşmesinde, psikolojik destek görmesinde, kendini güçlü hissetmesinde olumlu işlevler gösteren kuaförler; toplumsal cinsiyet eşitsizliklerinin yeniden üretilmesi ve gösterişin piyasalaşması açısından ise olumsuz işlevler üstlenmektedirler. Güzellik imajı konusunda kadınlar arasında göze çarpan rekabet bir "güzellik sosyalleşmesi" meydana getirmektedir. Söz konusu imaj rekabeti ortamında tüm aktörlerin biçimsel pratikler sergilemesi ve asgari müştereklerde buluşması bizi sürekli güncellenen ve genişleyen "güzellik sözleşmesi"ne götürmektedir.

Anahtar Kelimeler: Kadın kuaförü, imaj, güzellik sosyalleşmesi, toplumsal cinsiyet, güzellik sözleşmesi.

ABSTRACT: This study based on qualitative research method is about the hairdressers in different districts of Ankara and their female customers. It focuses how the femininity images of female customers differ according to their lower, middle and upper socio-economic levels in the hairdresser saloon. A detailed interview with 50 women and 15 hairdresser workers residing in different districts and having different social positions was made for understanding the meaning and importance of hairdressers in the female world. It was understood that

* Bu araştırma, Niğde Ömer Halisdemir Üniversitesi Bilimsel Araștırma Projeleri Koordinasyon Birimi Koordinatörlüğü'nce desteklenen SOB2016/03-BAGEP numaralı ve 2016 tarihli Kuaförlerde Yapılandırılan Kadınlık Imajının Sosyolojisi: Karşılaştırmalı Ankara ve Niğde Örnekleri adlı projeyle elde edilen verilerle hazırlanmıştır.

** Dr. Öğretim Üyesi - Niğde Ömer Halis Demir Üniversitesi Fen-Edebiyat Fakültesi Sosyoloji Bölümü/Niğde - ercangecgin@ohu.edu.tr

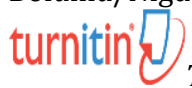

This article was checked by Turnitin. 
visiting hairdressers has increasingly turned into a necessary service for the women having different socio-economic levels in terms of their image and identity; but that the way of getting this service changes according their status of class. In consideration of the findings, the hairdressers were categorized according to their functions and women's purpose of use. It was also observed that while the women of lower socio-economic levels are liable to use the hairdressers as the extension of their houses, the tendency of using them instrumentally increases for the ones of the upper levels. As a result of the study, the hairdressers were released as having dual functions in the lives of women. The hairdressers having positive functions for women in their image combination, socialization, psychological support and strong feeling has negative functions in terms of reproducing gender inequalities and creating a marketable appearance. The competition on the image of beauty between women creates a "beauty socialization". We reach a continually updated and widened "beauty contract" with the formal practices of the whole actors and their meeting on a common ground in the mentioned competition area of image.

Keywords: Hairdresser, image, beauty socialization, gender, beauty contract.

\section{Giriş}

Estetik kaygı ya da imaj, kent hayatının önemli kültürel unsurlarından biri sayıla gelmiştir. Bu yüzdendir ki estetik, Antikçağ düşünürlerinden Aydınlanma Çağı'na, moderniteden postmoderniteye kadar pek çok filozofun gündemine girmiştir. Estetiğin vazgeçilmez bir pratiğe dönüşmesi ve modern çağın buna uygun yaşam çerçeveleri inşa etmesi Ferry'nin (2012) "homo esteticus" adını verdiği estetik odaklı insan modelini ortaya çıkarmıştır. Modern çağın yeni kent kültüründe estetik, daha geniş toplumsal alanlara kaymış ve Elias'ın (2013) uygarlaşma bağlamında açıklamaya çalıştığı kişinin dışsal ve içsel davranış tarzlarının inceltilmesi süreciyle yeni anlamlar kazanmaya başlamıştır. Davranış biçimlerinin metropol hayatının derinleşmesine paralel olarak imaj üretimine doğru kaymaya başlaması, yeni karmaşı etkileşim süreçlerini de beraberinde getirmiştir. Modern hayatın en derin sorunlarını bireyin çevreleyen toplumsal güçlerin ve tarihsel koşullar ile dişsal kültürün karşısında kendi bireyselliğini ve özerkliğini korumaktan doğduğunu belirten Simmel (2009:315), metropole özgü bireysel tipin psikolojik ve sosyolojik boyutlarına dikkati çekmiştir. Bugünün metropole özgü bireysel tipin kültürel davranışlarına baktığımızda, imaja dayalı etkileşimlerde bulunmanın baskın olduğunu görmekteyiz. Kuaför salonları veya güzellik merkezleri gibi yerlerin, imaj kültürünün üretim veya yapılandırma sahaları olarak modern çağın vazgeçilmez uğrakları haline geldiklerini, başka bir deyişle imaj sahibi olmanın veya kuaföre gitmenin kentli bireyin sosyalleşme biçimleri arasında zorunlu ritüellerden biri olmaya başladığını ifade edebiliriz. Bu toplumsal gerçeklikten hareketle, bu çalışmanın ana amacı da kuaför eksenindeki imaj üretim sürecinin ve onun etrafındaki sosyal etkileşimlerin sosyolojik niteliğini keşfetmek olmuştur. 
Kapitalizm, sembolik metaların dolaşımını Adorno'nun (2007) "kültür endüstrisi" ş̧eklinde tarif ettiği ve günümüzde de "kitle kültürü" şeklinde karşımıza çıkan olguyla gerçekleştirmektedir. Nitekim "moda", böylesi bir kültürel halenin ürünü olarak ortaya çıkmış ve toplumsal sınıfların birbirinden sembolik ayrımlar göstermesine aracılık etmiștir. Modern üretim koşullarının imajlar dolayımıyla devasa bir gösteri birikimine dönüştüğünü dile getiren Debord (2006), modern dönem toplumunun bir gösteri pazarı içinde olduğunu belirtmiştir. Kuaförler de artık gösteriş toplumunda vazgeçilmez uğraklardan biri haline geldikleri için her boyutu ile incelenmeye değerdirler. Kuaförler, birden fazla sosyal ilişki biçimlerinin yapılandırıldığı alanlardır. Kuaförde sadece imaj ve beğeni kalıpları yapılandırılmaz; aynı zamanda bu yapıların gömülü olduğu veya bu yapıların taşıyıcı ilişki zeminleri de birlikte inşa edilir. Kuaför ile müşteri arasındaki ilişki, müșterilerin kendi aralarındaki ilişkileri, kuaför çalışanlarının kendi aralarındaki ilişkileri ve müşterilerin kuaföre gitme potansiyeli olan diğer kişilerle olan ilişkileri gibi iç içe geçebilen ilişki kümeleri söz konusudur. Dolayısıyla çok geniş bir "güzellik sosyalleşmesi" yaşanabilmektedir. Bütün bunlardan hareketle, Ankara özelinde kuaföre giden kadınların ve kuaför çalışanlarının bu süreci nasıl deneyimlediklerini, anlamlandırdıklarını ve nasıl bir etkileşim süreçlerinden geçip sosyalleștiklerini ortaya sermek gayesiyle bu çalışma gerçekleştirilmiştir.

$\mathrm{Bu}$ araştırmanın amacl, Ankara örneğinden hareketle kuaförün kadınların dünyasındaki bugünkü yerini, rolünü ve anlamını ortaya çıkarmaktır. Dolayısıyla araştırma, imajın kuaförlerde, sosyolojik açıdan "nasıl gerçekleștiğine" ve bunun "nasıl bir sosyalleșme süreci" içinde yapılandırıldığına odaklanmıștır. Araștırma, nitel araştırma yöntemlerinden "durum çalışması"na uygun şekilde gerçekleştirilmiştir. Durum çalışması araştırması, araştırmacının gerçek yaşam, güncel sınırlı bir sistem (bir durum) ya da belli bir zaman içerisindeki çoklu sınırlandırılmış sistemler (durumlar) hakkında çoklu bilgi kaynakları (örneğin gözlemler, mülakatlar, görsel-işitsel materyaller ve dokümanlar ve raporlar) aracılığıla detaylı ve derinlemesine bilgi topladığı, bir durum betimlemesi ya da durum temaları ortaya koyduğu nitel bir yaklaşımdır. Durum çalışmasındaki analiz birimi birden fazla durum (çok mekânlı çalışma) veya tek bir durum (tek mekânlı çalışma) olabilir (Creswell, 2013:97).

Nitel araştırma yöntemine dayalı durum çalışması deseninin uygulandığı bu araștırmada; kadınların sınıfsal, mekânsal ve kültürel farklılıklara göre kuaföre gitme pratiğinin nasıl değiștiğine dair bulgular birden fazla teknik kullanılarak keşfedilmek istenmiştir. Bu doğrultuda hem kuaför sahipleri ve çalışanlar ile hem de kadın müşteriler ile yarı yapılandırılmış soru formları aracılı̆̆ıyla derinlemesine görüşmeler 
gerçekleştirilmiştir. Yüz yüze görüşmelerin dışında internet üzerinden de derinlemesine görüşmeler yapılmıştır. Kuaförlerle yapılan görüşmeler kendi çalışma ortamında yapılırken gözlemlerden de yararlanılmıştır. Kuaförler, semtlerin ana cadde ve sokaklarında bulunan kuaförler birbirlerine yakın olmayacak şekilde ve farklı profilleri yansıtacak nitelikte, amaca uygun örneklemle seçilmiştir. Genel amaç doğrultusunda Ankara kent merkezinde, sosyo-ekonomik düzey bakımından alt, orta ve üst gelir gruplarına göre ikamet eden kadın müşteriler ve kuaför hizmeti verenlere ulaşılmaya çalışılmıştır. Keçiören'e bağlı İncirli, Mamak ilçesine bağlı Kayaş semtlerinde alt; Çankaya ilçesinde Dikmen ve Öveçler semtleri orta; Birlik Mahallesi ve Çayyolu semtlerinde ise üst sosyo-ekonomik ve sosyo-kültürel kesim kabul edilerek bu semtlerde oturan kadın müşteriler ve kuaför hizmeti verenlerle görüşmeler gerçekleştirilmiştir. Keza farklı sosyal katmanlara hitap etme konusunda çeşitlilik gösteren Kızılay semtinde de uygulamalar gerçekleştirilmiştir. Bu semtlerin her birinde en az bir kuaförle derinlemesine görüşme yapılmıștır. Araştırma, Haziran-Ağustos 2016 aylarında gerçekleştirilmiştir. Toplamda 60 kadın müşteri ile 20 kuaför çalışanı ile görüşmeler yapılmıştır. Kuaför sahiplerinin 3'ü dışındakilerin tamamı erkektir. Kuaförlerde en küçügü 30, en büyügü 50 yaşındadır. Kadın müşterilerde ise en düşük 18, en yüksek 62 yaşındadır. Çoğunluk bekârdır. Meslek bakımından çeşitlilik söz konusudur. Alt sosyoekonomik düzeydekilerde çoğunluk ev hanımı ve iş̧̧i, orta düzeyde kamu çalışanı, üst düzeydekiler de ise doktor, öğretim üyesi gibi profesyoneller yer almıştır. Eğitim durumlarında da çeşitlilik söz konusudur. Araştırma bulgularının analizinde kadın müşteriler "AK", kuaför çalışanlarından erkekler için "AKE", kadınlar içinse "AKK" şeklinde numaralı kodlar kullanılmıştır.

Araştırma, betimsel ve açıklayıcı tarzdadır. Kuramsal çerçeve olarak tek bir yaklaşıma bağlı kalınmamış, kültürel tüketim farklılıklarının sınıfsal farklılıklarla ne derece uyuştuğuna yönelik olarak Bourdieu'nün (2015); kuaförlerin olumlu işlevleri, bozuk/olumsuz işlevleri (bağlama ve kime yaradığına göre), açık (görünür) işlevleri gizli işlevleri ve işlevsel alternatifleri (muadili) açısından Merton'ın (1968) kavram setlerinden istifade edilmiştir. Bunlar dışında da açılklayıcı modellerden yeri geldiğinde yararlanılmıştır. Bourdieu (2015), alışkanlıklardan ziyade kendiliğinden yatkınlıkları vurgulayan, kişilerin ait oldukları sosyal dünyalara/sosyal konumlara dair bilişsel ve pratik yönlü bir davranışı ifade eden "habitus" kavramını kullanır. Kişiye yatkınlıklar sunan habitus, inşa edilmiş sürecin bir nüvesi olduğu kadar aktif bir dönüştürücülüğü/failliği de taşımaktadır. Habitus, belirli bir sınıfsal durumun sosyal inşasında katalizörlük işlevi üstlenmektedir. Kuaförde hizmet alanların toplumsal konumları ve habitusları da pasifliği değil, yeri geldiğinde veya bağlama göre faillik 
gösterebilmektedir. Gündelik hayat pratiklerinin estetik yargıları, beğeni kalıpları, gösteriş örüntüleri, imaj dünyaları hem sınıfsal açıdan nesnel bir imkânı gerekli kılar, hem de sınıfsal ayrımın iç içe geçtiği statü farklılığının kültürel görünüme dair bir tazyiki içerir. Kuaför salonlarında alınan hizmet ve imaj odaklı sosyalleşme ile etkileşim biçimleri böylesi toplumsal konfigürasyonun temsilini sunar bizlere.

Makalenin genel içeriğinden bahsedecek olursak, bulgulardan hareketle, ilk olarak kuaförün kadınlar dünyasındaki anlamı ve kuaförün cinsiyeti üzerine durulmuş, sonraki bölümdeyse kuaförün kullanıma ve işlevlerine göre ayrımlara yer verilmiştir. Alt başlıklar şeklinde analiz edilen bu bölümler bulgulardan hareketle ulaşılan istihraçlar olmuşlardır. Sonuç kısmındaysa kuaförün ve kuaföre gitme pratiğinin sosyalleşmenin ötesine geçecek şekilde yeni bir güzellik sözleşmesi yarattığına vurgu yapılmıştır.

\section{Kuaförün Kadınlar Dünyasındaki Anlamı ve Kuaförün Cinsiyeti}

Kuaföre giden kadınların kuaförü anlamlandırma biçimlerinde farklılıklar olsa da kuaförün giderek vazgeçilmez bir uğrak olduğuna yönelik ortak bir anlayış göze çarpmaktadır. Saç kesimi, boyası ve bakımı başta olmak üzere, manikür, pedikür, ağda gibi diğer hizmetler için de kuaföre gidilmektedir. Kuaförün anlamlandırılma biçimlerinde; güzelliğin, değişimin, estetiğin, yenilenmenin, tazelenmenin, rahatlamanın, daha iyi anlaşılıyor olma gibi hallerin ifadeleri katılımcılar tarafından sıklıkla dile getirilmiştir. Müşterilerden bazılarının görüşleri şöyledir:

A21 (23 yaşında/öğrenci): Aklıma ilk saç kesimi geliyor. Saçlarımı istediğim gibi kesmesi önemli ve yeterli. Kadın dünyası için adeta bir kendini var etme ortami.

A23 (35 yaşında/arkeolog): Yenilik, tazelenmek, özgüvenin yükselmesidir kuaför... Kuaförüm benim kurtarıcım.

A27 (26 yaşında/halkla ilişkiler): Kuaför, ilk olarak kadınların güzelleşmek için gittikleri bir yer. Bunun yanı sıra moral düzeltmek ve hatta dertleşmek için de gidiliyor. Kuaför denilince aklıma ilk gelen şey aynalar, fön makinası ve bazen de gereksiz samimiyet gösteren insanlar. Kuaför benim için çok önemli. Kesinlikle işini iyi yapıyor olmalı.

A47 (33 yaşında/yatırım danışmanı): Şöyle sıralayabilirim: kuaför, zaman kaybını engelliyor, yaptığım iş dolayısı ile her zaman şık ve bakımlı görünmem gerekiyor. Hayat standardı ve alışkanlık da etkili. En önemli sebep ise "üşengeçlik".

Kuaförün ekseriyetle erkek cinsiyetinden olması da önemli gözlemler arasındadır. Kuaförün kadın olduğu yerler ağırlıklı olarak kenar mahalleler ve alt-orta sosyo-ekonomik durumdakilere hizmet verenlerdir. Üst sinıfa 
hizmet veren yerlerde de kadın çalışanlar söz konusudur ancak bunlar daha özel işlemlerde (kaş alımı, manikür, pedikür vb) çalışmaktadırlar. Özellikle saç kesim ve bakımında erkek tercihi ön plandadır. Görüşmelerde her ne kadar kadın müşteriler cinsiyeti önemsiz gördüklerini ifade etmiş olsalar da, son kertede ağırlıklı tercih erkek kuaför olmaktadır. Kadın tercih edenler de söz konusudur ki bu müşterilerin gerekçeleri arasında yaşam tarzı (değer sistemleri, özellikle de muhafazakârlık) ile hemcinsinin kendisini daha iyi anlayacağına dair görüşler yer almaktadır. Özellikle mahalle aralarında ve bu makalede "Evin Uzantısı Olarak Kuaför" tarzındaki yerlerde kadın kuaförlere daha sık rastlanabilmektedir. Tesettürlü müșterilerin tercihlerinde de kadın ön plandadır. Diğer taraftan cinsiyete dayalı iş bölümlerinin de dikkate alındığı görülmektedir:

A55 (44 yaşında/eczacı): Erkek olmalı. Çünkü kadınların bu konuda çok yetenekli değil. Daha önce gitmişliğim var. Mesela manikür pedikür makyajı çok güzel yapıyorlar ama saçta iyisine rastlamadım. Ama şimdi gittiğim kuaföründe bir kadın fönü güzel yapıyor.

A42 (48 yaşında/memur): Kuaförüm erkek ama özellikle tercih etmedim kadında olabilirdi baktım işini güzel yapıyor devam ettim. Sürekli ona gitme sebebim efendi saygılı olması ve az konuşması.

Kuaförün cinsiyetinin önemsiz olduğu dile getirilse de çoğu müşteri tarafından erkek tercihinin ilk sırada geldiği söylenebilir. Çankaya'da, üst sınıfa hizmet veren kuaför sahibinin AK1 (35 Yaşında) gözlem ve görüşleri durumu özetler niteliktedir:

Çok karşılaşıyoruz bu durumla. Bayan arkadaş var zaten burada. İyi eğitimli. Ama kadınlar kuvvet arıyorlar. Bayan olunca saçıma yumuşak fön çekiyor diyor. Erkekteki sertliği seviyor. İște anlatamıyorsunuz, kadındaki o bilinç şeyi işte. Önyargılı geliyorlar.

A51 (27 yaşında/öğretmen): Erkek tercihim, çünkü daha dobra oluyorlar.

Kadınların genel olarak erkeğin gözünde görünme istenci, kadın kuaförün kendisinden daha güzel olmasını istemeyebileceğine dair kuşku gibi pek çok gerekçe, erkek tercihinde etkili olabilmektedir. Kadınlar arasındaki açık ve gizli imaj rekabeti, kendini bir erkeğin "ayna"sında görme istenci gibi hususlar yanında, bazı sohbet konularında erkeğin görüşünü almak gibi çeşitli "açık" ve "örtük işlevler" (Merton,1968) açısından da erkek tercih konusu olabilmektedir. Bazı erkek kuaförlerin kadınlara özgü görülen bazı davranış ve dilsel iletişim içinde olmaları da bazı kadın müșteriler tarafından hoș karşılanabilmektedir. Kuaför- müşteri ilişkisinde bu durum göreli olarak güven ilişkisine dayalı samimiyeti de arttırabilmektedir. Ayrıca araştırmada, estetik hazlarının daha güçlü 
olduklarına inandıkları eșcinsel kuaför tercihinde bulunduğunu belirten kadın müşterilere rastlanıldığını da not etmek gerekir.

\section{Kullanım Amaçlarına Göre Kuaförler}

Kadınların kuaförleri amaçlarına göre kullanım kriterine göre iki kategori geliştirebiliriz. İlki kuaförü sadece bakım ve imaj maksadıyla kullananlardan müteşekkil "Araçsal Olarak Kuaför"dür. İkincisi, güzelleşme amacı yanında birincil ilişkilerin egemen olduğu "Evin Uzantısı Olarak Kuaför"dür. Bunların Weberyen anlamda birer ideal tipleştirme olduğunu, yüzde yüz somut durumla örtüşmeyebileceğini ancak kuaförleri belirli kullanım niteliklerine göre analizi etme hususunda anlamlı araçlar olduklarını vurgulamak gerekir. ${ }^{1}$

İmajın yapılandırılmasındaki "yapılandırma" kavramı, Giddens'ın (1999: 60-75) yapı-fail/eyleyen arasındaki diyalektik ilişkiyi temellendirdiği "yapılaşma kuramı" eksenindeki "yapının ikiliği" çerçevesinde düşünülebilir. Buna göre, yapı bireylere dışsallıktan ziyade belirli fail durumlarında daha içseldir; yani yapı hem kısıtlayıcı hem de ona olanak vericidir. Failin/eyleyicinin belirleyici tarafı olduğu kadar dönüştürücü nitelikleri de vardır. Toplumsal ilişkiler zaman-uzamda yapının ikiliği sayesinde yapılaşır. Dolayısıyla yapı, düzenlemiş olduğu davranışın hem aracı hem de sonucudur. Üretilen eylem yapıyı da üretir. "Eylemin üretilme anı aynı zamanda, toplumsal yaşamın gündelik açıdan yürütüldüğü bağlamlardaki yeniden üretilme anıdır da" (Giddens, 1999:70). İmaj üretiminde ve imajın toplumsal ilişkiler dolayımıyla yeniden üretiminde yapının bu ikiliğini görmek olanaklıdır. Kadınlar bir taraftan imaj dünyasının güzelleşme kiplerine uygun hareket ederek imaj yapısını üretmektedirler diğer taraftan da yaratıcı pratikleriyle bunu dönüștürebilmektedirler. Bu kuaför hizmeti veren için de geçerlidir. Bugünün dünyasında kuaföre gitmenin yapısal açıdan dışsal zorlayıcı boyutu olmakla birlikte, içsel açıdan keyif almak, rahatlamak, farklı stiller geliştirmek, farklı olma çabaları açısından da dönüştürücü boyutu bulunmaktadır. Böylece güzelleşme/imaj etrafındaki tüm toplumsal pratiklerin bağlamı da yeniden üretilmiş olmaktadır.

\subsection{Araçsal Olarak Kuaför}

$\mathrm{Bu}$ tipleştirmede müşteriler kuaförü, ağırlıklı olarak imaj ve bakım için kullanmaktadırlar. Sosyalleşmek de mümkündür fakat öncelik olan

1 Söz konusu kavramsallaştırmada; kadın müșterilerin tek yönlü kuaför hizmetini almalarından ziyade, kuaförle etkileșim süreçleri, güzelleşme etrafında örülü sosyalleșmenin bütünsel boyutları dikkate alınmıştır. Diğer taraftan kuaförlerin ortaya çıkan beğeni biçimlerine hâkim olmalarının da etkileşimde dahli vardır. Dolayısıyla kuaförün de gerek yapısal gerekse dönüștürücü istikamette aktörlügü bulunmakta ve imaj inşası konusunda karşılıklı bir etkileşimden hareket edilmiştir. 
hizmet alımıdır. Önceki kategoriye göre ilişkiler mesafelidir. Orta ve üst sınıfta çoğunlukla bu tip kuaför göze çarpmaktadır. İmaj yapılanmasında araçsal bir zeminde tutulan kuaför ile ilişki aktif, pasif ve müzakereci şeklinde olabilmektedir.

A2 (26 yaşında/işsiz): Kuaföre bir bayan olarak öz bakımım için; önce kendim için, sonra çevreye estetik gözükmek için gidiyorum. Özellikle kaş, saç bakımı.

Böylece imaj inşası amacına göre kuaför-müşteri ilişkisinde üç alt tipin ortaya çıktığını keşfetmekteyiz. Kuaförü kullanma biçimi, imaj oluşturma hususunda kuaföre duyulan güven ve sadakat, imaja yaklaşım biçimi ve saç stillerini belirleme konusunda izlenen yollar açısından elde edilen bulgulardan hareketle bu sınıflandırmalara ulaşmak mümkündür.

\subsection{1. İmaj Yapılandırıcısı Ya Da "Kadını Baștan Yaratan" Olarak}

Kuaför: Bu tipleştirmede, imajın üretilmesinde kuaför belirleyici aktördür. Hizmet alanların saç stillerini öneren kuaföre sadakat ve güven yüksektir. İmaj üretiminde kuaför, aktif belirleyici iken müşteri çoğunlukla pasif konumdadır. Elbette bu ilişkinin tonu değişmektedir ancak kuaför son kertede belirleyicidir ve imajın lokomotifidir. Nihayetinde kuaför, "saf imaj yapılandırıcısı" pozisyonundadır. Kuaföre güven arttıkça ve hizmet alma süresi yılları buldukça kuaför ile müşteri arasındaki ilişki arkadaşlık hukukuna doğru da kayabilmekte ancak kuaföre gitme amacı yine de, kuaförün açık işlevleri dolayısıyladır.

A10 (35yaşında/akademisyen): Kuaförümü hiç değişmem çok mecburi durumlar dışında. Sebebi ise ne istediğimi bilmesi.

A11 (25yaşında/öğretmen): Aynı kuaföre gidiyorum çünkü her yeni kuaförü tanımak kendini tanıtmak çok zor, benim ne istediğimi bilmeli.

Alışkanlık, hizmet biçimi ve kalitesi, güven gibi gerekçelerle aynı kuaförlerle devam etme eğiliminin çok yüksek olduğunu gözlemlemekteyiz. Güvenin getirdiği sadakatli müşteri ilişkisi bir nevi "tebdili mekânda ferahlık vardır" sözünü doğrulatmaktadır. Kuaförden memnuniyetin belirli bir zaman sonra aynı ortak algıya ve üzerinde anlaşılan bir tarz ya da stile veyahut bir yenilik yapılacaksa onun beğeni yapısına göre gerçekleştirileceğinin bilgisine bir güven bulunmaktadır. Williams'ın (1961) belirli bir dönemin veya belirli sınıfsal halin kolektif kültürel eğilimlerini işaret eden "his yapısı" kavramını buraya uyarlarsak, kuaför ile müşteriler arasında sadakat açısından bir his yapısının olgunlaştığını söyleyebiliriz. Böylece bir aidiyet duygusu da şekillenmektedir. Diğer taraftan yeni kuaförler keşfetmeyi, değişimi farklı tarz veya imaj yaratıcısında deneyimlemeyi isteyen çok az kadının olduğunu söyleyebiliriz. Dolayısıyla risk almaktan ziyade bilinenle devam etme eğiliminin ağır bastığını, tercihlerde muhafazakâr bir tutum takınıldığını 
görmekteyiz. Kuaförünü değiştirenler ise genel olarak hizmet kalitesinden memnuniyetsizlik yaşayanlar veya çalışanların tutumundan rahatsızlık duyanlardır.

Saç stiline dayalı imaj edimi konusunda, sınıfsal ve sosyal statüler bağlamında baktığımızda sembolik sermaye oluşturma açısından bir farklılaşma eğilimi göze çarpmaktadır. İmajın sembolik sermayeye dönüşmesi açısından, ekonomik sermayesi daha yüksek olan üst sınıfın farklı imaja sahip olma istenci ve girişiminin daha yoğun olduğu araştırmada gözlemlenmiştir. Hatta bazılarının kuaföre yaptıkları yüksek harcamayı sembolik güç olarak ifade etmeye çalıştıklarına da şahit olunmuştur. Üst sınıfın kendi yaşam dünyasındaki güç ilişkileri de düşünüldüğünde farklı imaj denemelerine girişmesi anlaşılabilir bir durumdur. ${ }^{2}$ Ancak orta ve hatta göreli daha alt sınıfta olmasına rağmen öğrenci kadınların da bu türden imaj denemelerine (lakin daha az kaliteli hizmet sunan kuaförlerde) sıklıkla girdiklerini de belirtmek gerekir.

Kızılay'daki bir kuaförün (AKE10) şu ifadesi imaj yapılandırılmandaki işlevlerini özetler niteliktedir: "Allah kadınları yaratıyor, biz ise onları baștan yaratıyoruz.". Nitekim müşterilerden A41 (öğretmen) bunu teyit ediyor gibidir: "İmaj önemli, çünkü bıraktı̆̆ın izlenimdir. Vazgeçilmez bir durumdur çünkü kişinin kendini görünüşünü değiştirme ve bundan kaynaklı olumlu dönütler alması olumlu yönde etkide bulunmakta. Kuaförler artık sadece saç kesimi ile sınırlı değil farklı tarzlar saç tasarımlar ve makyaj ile kişiyi baştan yaratarak önemini artırmaktadır." A12 (20 yaşında) de bu görüşü desteklemektedir: "İmajı kuaförler yaratır bence."

Kuaför imaj yaratıcısı kimliği ile kendini daha fazla yetiştirme, geliştirme ve yeni saç stilleri kendisini sürekli güncelleme eğilimindedir. Yüz yüze eğitimler yanında sosyal medya da aktif olmak, paylaşımlar yapmak, imaj yapılandırıcısı kimliğinin itibarını daha da yükselten unsurlar olabilmektedir. Böylece müșterilerin kuaföre daha fazla "sanat" gözüyle bakış geliştirmeleri mümkün olabilmekte, güven ilişkisi güçlenebilmektedir. Kuaför, müşteriyi tanıdığı ölçüde onun nelerden hoşlandığını bilmekte, yani beğeni habitusuna hâkim olmakta ve önerilerini de buna göre sunmaktadır.

2.1.2. İmaj Yardımcısı Olarak Kuaför: Bu tarzdaki kuaför, ilk tipe göre daha pasif konumdadır. Müşteri beğendiği saç modelini kendisi seçip getirmektedir ve nasıl olması gerektiğini talimat şeklinde kuaföre

\footnotetext{
${ }^{2}$ Kuaför çalışanları ile kadın müşterilerin sınıfsal durumları ile statülerini dikkate alacak şekilde sembolik ve kültürel sermaye biçimleri üzerinden Üstüner ve Thompson'ın (2012) yapmış olduğu araştırma da benzer sonuçların elde edildiğini vurgulamak yerinde olacaktır.
} 
yaptırmaktadır. Öncekine göre yaygınlığı daha düşüktür. Kadının bir şekilde kendi kendisinin kuaförü olması durumudur ve bundan dolayı da sık sık kuaför değiştirebilmektedir. Kuaför, dolaylı konumdadır ve imaj yapılandırmasında sadece kolaylaștırıcı rol oynamaktadır. Kuaföre sadakat ve güven gevşektir. Müșteriler, sadece imajın inşasında "yardımcı" işleviyle kuaföre ihtiyaç duymaktadırlar.

A8 (25yaşında/öğretmen): Kuaförler bazı kadınlara imaj belirlemesinde yardımcı oluyor. İmaj önemlidir. Saçına göre klyafet seçiyorsun.

Kuaföre yaklaşımı son derece esnek ve zayıf olan bu kesimde anlık karar değişimleri söz konusu olabileceği gibi aynı kuaföre gitse bile farklı saç modellerini kendisinin kuaföre yaptırması eğilimi ağır basmaktadır. Saç stillerini kendilerinin belirlediklerini belirtenlerin en çok başvurdukları kaynağın internet, internette de "instagram"ın olduğunu belirtmek gerekir.

A13 (25yaşında/öğrenci): Modeli kendim seçiyorum, uygulanabilirliğini de kuaföre soruyorum. Yine sonuçta kendi istediğime göre yaptırırım ama. Günlük hayattan ya da medyadan gözüme takılabiliyor.

Kuaför kullanımın bu tipinde bireylerin kendi kendinin imaj girişimcisi olma eğilimi ağır basar. 1930'da Vogue'deki "Helat Motor" reklamının "siluetinin heykeltırașı" (akt. Vigarello, 2013: 238) sloganında temsil edilen kendi güzelliğinin heykeltıraşlığını bu tipleştirmede görmemiz mümkün. Dolayısıyla kuaförler, güzellik elçileri veya sadece yardımcı pozisyonda konumlanabilmektedirler.

2.1.3. İmaj Aracısı veya Ajanı Olarak Kuaför: Bu kategoride ise kuaför ile müşteri arasında daha müzakereci bir ilişki söz konusudur. Kuaföre imaj aracısı olma rolü biçilmekte ve kuaför de bu bilinçle hareket etmektedir. Asgari düzeyde tanışıklık bu durumu kolaylaştırmaktadır. Müşteri beğendiği modeli başka yerlerden (çoğunlukla internet ortamında) bulabilmekte; ancak bunu kuaförüne de danışarak hayata geçirmektedir. Ağırlık merkezinde, ne kuaför ne de müșteri vardır; ikisinin müșterekliği egemendir. Yani bir müzakere söz konusudur. Kuaför müşterisine yeni önerilerde de bulunabilir ve bunlar kabul de görebilir. Bu açıdan imajın yapılandırılışında kuaför "ajan" veya "aracı" işlevi göstermektedir. Keza müşteri de yeni öğrendiklerini kuaförlerle paylaşarak o da pasif bir imaj ajanı rolü oynayabilmektedir.

A37(37yaşında/akademisyen):İmaj için kuaförler bir aracıdır, asıl olarak imajı oluşturması gereken kişinin kendisidir. Tek önemi bunun için aracı olmaları bence. Aksi uygulamalar tornadan çıkmış ürün gibi.

A10(35 yaşında/akademisyen):İmaj çok önemli bence. İş dünyası için de imaj vazgeçilmezdir. Kuaförüm beni iyi tanıdı̆̆ı için imaj önerilerinde bulunuyor. Ama beni tanımayan kuaförlerin bana imaj önermesini istemem. 


\subsection{Evin Uzantısı Olarak Kuaför}

$\mathrm{Bu}$ kuaför tipinde birincil ilişkilerin daha yoğun şekilde yaşandığını görmekteyiz. Daha çok alt sosyo-ekonomik durumdaki kesimin tercihiyle inşa edilen bu tip çoğunlukla mahalle aralarında bulunur. ${ }^{3}$ Sokak aralarına gidildikçe kuaför çalışanlarının cinsiyetinde kadına lehine bir artış da göze çarpar. Nitel araştırmanın açısından bu bilgi genelleştirilemezse de eğilim hakkında ipucular vermektedir. Bu tipteki kuaför kullanımında kadınlar yarı-müşteri pozisyonunda gibidirler. Kuaför, bakım hizmeti açısından birincil işleviyle değil daha çok sosyalleşme gibi ikincil düzeydeki işlevleriyle kullanılır. Kuşkusuz, bakım hizmeti de alınabilmektedir ancak kuaföre geliş sebepleri ve sıklıkları dikkate alındığında hizmet alımının sosyalleşme biçimine yedirilmekte olduğunu söylemek gerekir. $\mathrm{Bu}$ kuaförlerin çoğunluğunun kapı önünde masa ve sandalyelerin kurulu olduğu ve komşu kadınların da sıklıkla gelip oturduğu araştırmada gözlemlenmiştir. Evden yapılan yemeğin, kekin ya da pastanın getirilip paylașılması, kuaförde çayın/kahvenin yapılıp sohbet edilmesi bu türden sosyalleşmelerdendir. Bazı kuaförlerin ayrı mutfağı da olabilmektedir. Hizmet alımı dışında, sohbet, çay içmek, derdini paylaşmak veya zamanı geçirmek, alışverişe ya da pazara giderken uğramak, yapılan yiyeceği tattırmak gibi maksatlarla kuaföre gidilebilmektedir. Kuaförler genellikle apartmanların girişinde olduğundan dolayı onunla yüz göz olma ihtimali çok yüksektir. Dolayısıyla da evin uzantısı gibi görmektedir kuaförü kadınlar. Kuaförün sahibi ve çalışanları kadın olunca bu uzantı daha yakın veya samimi ilişkiler doğurabilmektedir. Keza kuaförün erkek olduğu durumlarda da bu yönde ilișkiler gelişebilmektedir.

Dikmen semtinden A1 (45yaşında/ev hanımı) kuaförün mahalledeki rolünü şu şekilde özetlemiştir:

Kuaförümüz bizden biri, zamanımız olduğunda gelip konuşuruz, çay da içeriz. Düğünlerde nişanlarda saçımızı yaparız. Çalışan kızlarımız da gelirler buraya fön çekmeye. Bir işimiz düssse, paraya sıkışsak yine buranın kapısını çalışıyoruz.

Mahalledeki kadın kuaför, hem mahalledeki girişimci veya esnaf hem de mahalledeki kadınlarla dayanışma gösteren önemli bir aktördür. Bundan dolayı bir kuaförden daha fazlasını temsil etmektedir. Ancak kuaförün cinsiyetine yönelik müșterilerin erkek tercihi burada olumsuz bir

\footnotetext{
3 İstanbul özelinde, bazı semtlerde (Beyoğlu, Gümüșsuyu vb) ve belirli sosyal sınıfa hitap eden kuaförler var iken, değișen zaman ve toplumsal çehreyle birlikte pek çok semtte kuaförlerin açıldığını, müşterilerin farklılaştığını belirten Yumul (2004), müșterilerin çoğunluğunu çevrede yaşayanların oluşturduğu bu tiptekileri "mahalle kuaförü" olarak tanımlamıștır.
} 
tesir bırakmaktadır kadın dayanışmasına. Zira mahallelerdeki bazı kadın kuaför çalışanları, kadın müşterilerinden özellikle de genç ve çalışan kesimin az geldiğini ve tercihlerinin erkek çalışan kadın kuaförü olduğunu belirtmişlerdir. Buna karşın yine de her kesimden müşterilerinin olduğunu da ifade etmişlerdir. Ancak çoğunlukla ev kadınlarının ve düşük gelirli kesimin genel müşteri kitlesi olduğunu görmekteyiz. Güzelleşmek, imaj sahibi olmak, kamusal alanın genişliği ile orantılı ve toplumsal aynayla da bağlantılı olmasından ötürü çoğunlukla bu istekler süreklilik arz etmez. Belirli özel günlerde bu talepler yoğunlaşmaktadır. Dolayısıyla sosyalleşmek, kuaföre gitmenin en önemli anahtarı olmaktadır. Sosyalleşme biçimlerinin birbirine yakınlığını kuaför- müşteri arasındaki iletişimden de anlayabilmekteyiz. Nitekim bu tipteki kuaförler "abla" ya da "abi" olarak çağrılmaktadır genelde. İlişkiler daha samimi ve sıcak olmaktadır.

\section{3. İşlevlerine Göre Kuaförler}

Kuaförlerin farklı amaçlar doğrultusundaki kullanımına dair analitik ayırımlarla birlikte düşüneceğimiz bir başka ayırım noktası işlevler dolayısıyla olanıdır. Araştırmada kuaförler kadınlar için bağlamlara ve durumlara göre olumlu, olumsuz ve alternatif işlevler üstlenebildiği keşfedilmiştir. Başta imaj yapılanması olmak üzere pek çok başlıkta bu işlevsel özellikleri sınıflandırabiliriz.

\section{1. İmaj Yapılandırma Sahası Olarak Kuaför}

Gösterinin imajlar toplamı değil bir toplumsal ilişki biçimi olduğunu belirten Debord'un (2006:13) “Gösteri Toplumu" tezi, imajın veyahut yanılsamanın geçerli hale gelmeye başladığı yeni toplumu işaret eder. Gerçek varoluşların ve kimliklerin değil de toplumsal ürünler olan imajlar vasıtasıyla kurulan ilişki biçimi esasında piyasa ilişkileri mantığından beslenir. Kültürün metalaşmasının yaygın bir hali olan bu süreç "kitle kültürü"nin halesinde yaygınlık kazanmıștır. Gürbilek (2016), 1980 sonrası gösteri odaklı dönüşen bu kültürel iklimi "vitrinde yaşamak" şeklinde tanımlamıştır. Yaşanan toplumsal değişimin gündelik hayattaki yansımasını ise Kozanoğlu (2001) "cilalı imaj devri" tanımlamasıyla kavramıştır. Bugüne geldiğimizde Atay (2017) "Meşhuriyet Çağı" nitelemesinde bulunmuştur. Kitle iletişim araçlarıyla giderek genişleyen, imaj benlikleri meydana getiren ve piyasa ilişkilerine dayalı gösteriş biçiminin hâkimiyet kazandığı bu sürece "gösteriş piyasası" diyebiliriz. Bu kavramdan kasıt, piyasa ilişkilerine ve piyasalaşmış imajlara göre sosyalleşmelerin baskın hale gelmesidir. Başka bir ifadeyle, piyasadaki rekabet mantalitesinin imaj rekabetine de kendi karakterini vermiş olmasidir. 
Görüntünün, fark edilmenin, imajın en önemli ilişki tipi olarak kodlandığı ve insanların birbirini imaj üzerinden tanımlamaya başlaması, gösterişin piyasalaşma sürecidir. Kuaför, bireylerin gösteriş piyasasında bireylerin farklı stillerle var olmanın, beğenilmenin, böylece benlik algısını güçlendirmenin araçlarından biri olmaktadır. Çankaya'nın Kolej semtinden kuaför AKE4'ün (32yaşında) şu tespiti önemlidir: Kadının kendine güveni geliyor. Kadının kuaförü psikoloğu gibidir. Kolay kolay vazgeçemez. Keza müşterilerde de imajın gösteriş piyasasındaki önemine dair önemli yorumlar bulunmaktadır:

A30(25 yaşında/işsiz):Kendimi iyi hissettiğimde imajımı tamamlamış olurum. Kadınlar için imaj çok önemli ve inanılmaz para harcayabilirler.

\subsection{Sosyalleşme Mekânı Olarak Kuaför}

Toplumsallığın doğasını sosyal etkileşimlerden hareketle kavrayan Simmel (2009:136) sosyalliği bir araya gelmenin oyun biçimi olarak görmüştür. Simmel'e göre (2009:139) sosyallik, doğası gereği eşitler arasındaki etkileşimi gerektirir ve "toplumsal oyun" olarak yaşanır. Ancak bu eşitlik, kişinin sosyallik değerini etkileşimdeki diğerlerinin de dâhil karşılıklı olarak nesnel içeriğin önemli kısmından vazgeçerek, kişinin herkes eşitmiş gibi davranmasına dayalı varsayım, sık sık gerçeklikten kopan bir oyun gibi veya bir sanat gibidir. Simmel'den hareketle, sosyalliğin benzer sosyal alanlarda kişiler arasında sohbet/konuşma, çıkar, çatışma, mübadele ve rekabet gibi etkileşim biçimlerinin olduğu; duygudaşlık, kıskançlık gibi duygularla harmanlanmış; taviz verme ya da koparma gibi manevraların süre gittiği, görsel ya da imaj etkileşimini de kapsayan bir dinamik süreç olduğunu söyleyebiliriz. Kuaför, sosyalleşmenin de mekânlarından biridir. Daha önce bahsettiğimiz üzere, "Evin Uzantısı Olarak Kuaför" tipi açık bir sosyalleşme biçimine sahip iken diğerleri daha örtük bir sosyalleşme eğilimine sahiptir.

Kuafördeki sosyalleşme, esas olarak "güzellik sosyalleşmesi"dir ve kuaförü de aşan, ilişkileri, etkileşimleri kapsamaktadır. Sosyalleşme biçimleri toplumsal sınıflara göre değişkenlik gösterebilmektedir. Sözgelimi alt sınıftaki kadınların (özellikle de çalışmayanların) kuaförde sosyalleşme süreçleri daha yoğun ve uzundur. Ev kadınları, işsizler ya da çok fazla kamusal alanda yer alamayanlar, Merton'ın (1968) kavramıla izah edecek olursak, "işlevsel alternatif" olarak kuaförü kamusal alan gibi kullanabilmektedirler. Böylece kuaföre gitmek, evden çıkmanın da anahtarlarından biri olmaktadır. Diğer taraftan, ataerkil yapının toplumsal kontrol ve denetim mekanizmalarından kopmasa bile geçici soluklanma işlevini de yerine getirir. Gerekçeleri farklı olsa da benzer soluklanma işlevi orta ve üst sınıftaki kadınlar için de geçerlidir. Üst sınıfa doğru gidildikçe kuaför ile müşteri arasındaki ilişki ya da müşteriler ile diğer müşteriler arasındaki ilişki; başta dil olmak üzere, sohbet konuları, yaklaşım biçimleri 
ve diğer konulardaki pratikler değişmekte ve sosyal mesafe artmaktadır. Yine de sosyal ortama ve sinıfsal bağlama özgü sosyalleşme biçimi ortaya çıkmakta ve farklılaşan tarzlara uygun etkileşim ritüelleri icra edilebilmektedir. Örneğin sosyalleşmenin en önemli lokomotiflerinden biri olan sohbet, toplumsal sınıfa, ortama ve müşteri bağına göre değișebilmektedir.

A38(35 yaşında/psikolog):Çoğu kimseyle yakın arkadaş-aileden biri gibi ilişkileri var. Bazı müşteriler için çok olumlu, işi olmadı̆̆ı halde dertleşmek için gelenlerle karşılaşıyorum "bir işim yok, konuşmaya geldim, canım sıkkın" diyeni duyuyorum. Bazen bu kadar yakın olmak istemeyen insanları rahatsız ediyor gibi. Özel yaşamla ilgili sorular bazılarını kızdırıyor.

A5(23 yașında):Kuaför bir bakıma dedikodu kazanı gibi. Veya kadınların networkünü genişlettiği bir mekân. Ya da yine kadınların sıkıntılarını diğer hemcinsleriyle konuşarak aşmaya da çalıştığı bir yer.

Orta ve üstü sosyo-ekonomik düzeydeki müşterilerin ilişkiyi genel olarak mesafeli tuttuğunu, arada güven ve samimiyet olsa bile "siz"li/ "biz"li konuşmayı tercih ettiklerini, kuaförlerinin de bu şekilde yaklaştıklarını belirtmektedirler. İstisnaları olmakla birlikte genel olarak mesafe korunmaktadır. Üst sinıflara hizmet veren kuaförlerde mesafe korunmakla birlikte hediye alış verişi gibi etkileșimler de yaşanabilmektedir:

A55(44 yaşında/eczacı):Gözlemlediğim kadarıla kuaförlerini çok seven kadınlar var orada. Mesela çalışan birisi var, onu sevenlerin ona hediyeler verdiğini ben gördüm. Ben de kendi kuaförüme yılbaşında hediye verdim. Kızım da öyle. Kapıdan girdiğimde hepsi isimle hitap eder. Cook saygillar. Mesafe hep var.

Alt sosyo-ekonomik düzeye hitap eden kuaförlerdeyse müşterilerle kurulan ilişkiler birincil düzeyde sürdürülebilmektedir. Kendisi ile abikardeş gibi olduklarını belirtenlere de rastlanmıştır. Samimiyet ilerledikçe ve güven arttıkça iletişimin dili de değişebilmektedir.

Saha araştırmasının ilk evrelerinde görüşmecilerin bazılarının dile getirmiş olduğu "kuaförün kadınların kahvehanesidir" șeklindeki görüş de sosyalleşmenin başka bir boyutunu teşkil ettiği için sonraki aşamalarda yeni görüşmecilere sorulmuştur. Evin Uzantısı Olarak Kuaför kategorisinde işlev gösterenler de bu yargı daha yüksektir. Stres atmak, rahatlamak ve genel olarak sosyalleşme bakımından kadınların kahvehanesi işlevi gördüğüne yönelik görüșe onay verenler olmakla birlikte, bunun kısmen geçerli olduğunu dile getirenler de olmuştur. Kahvehane nitelemesi ile birlikte "dedikodu merkezi" olduğunu ne sürüp eleștirenler de, bundan keyif alanlar da olabilmektedir. 
A58(25 yaşında):Bence kesinlikle kahvehane gibi. Sohbet çok yoğun buralarda. İlk müșterisine bile özel hayatıyla ilgili sorular soruyor kuaför gayet rahat biçimde. Kahkahalar, şakalar, çaylar, kahveler dönüyor küçük masalarda. Bence küçük esnaf șeklindeki kuaförlerde bu durum daha fazla. Yeni açılan hastaneye benzeyen güzellik merkezi gibi olan yerler daha profesyonel duruyor bu kadar samimi ortam yok. Bana bile ilk sorulan soru "Nişanlı misın?" olmuştu. Yok değilim desen "düşünmüyor musunuz?" şekline gidiyor yani. Konu konuyu her zaman açar.

Kuaför çalışanlarında da benzer yönde kanaatler hâkimdir:

AKE5:Evet katıllyorum dedikodu merkezidir. Öğrenciyken gelemeye başlayıp evlenip çoluk çocuk sahibi olduğunda da geliyor. Yaşantısını düşüncelerini tutumlarını her şeylerini biliyorsun. Erkekler için kahve neyse kadınlar için de kuaför öyledir. Kahvehanesidir.

Kuaförün kadınların kahvehanesi işlevine katılmayanlar da söz konusudur. Bunlar ekseriyetle "İmaj Yardımcısı Olarak Kuaför" yörüngesindedir ve sosyo-kültürel düzeyleri ile kültürel sermayeleri daha yüksektir.

\subsection{Bilgi Paylaşım ve Aktarım Merkezi Olarak Kuaför}

Kuaför, aynı zamanda sosyal bilgiyi toplama, yayma gibi işlevleri üstlenmektedir. Bakım ve güzellik alanından erkekler dünyasına, evlilikten aileye, siyasetten ekonomiye kadar pek çok konuya dair bilginin biriktiği ve yeniden servis edildiği yerlerden biridir kuaför. Her türlü toplumsal bilginin paylaşılmasında ve yayılımında kuaför çalışanı aktif rol oynar. Bilginin paylaşımında, hem kuaförün hem de müșterilerin kültürel sermayesi, başta konuşma olmak üzere genel davranış biçimleri, yaşları, cinsiyetler, meslekleri, medeni durumları, sosyo-ekonomik halleri ile statüleri etkili faktörlerdir. Örneğin kuaförün erkek olması, alınan hizmetle ilişkilendirildiği gibi sohbet etme biçimini de doğrudan etkileyebilmektedir. Özellikle sevgilisi, kocası ile sorun yaşayanlar veyahut yeni bir sevgili adayına nasıl yaklaşması gerektiğini bilmeyenler için erkek kuaför iyi bir fikir danışmanı işlevi görebilmektedir. Zira kuaförün benzer sorunlarla daha önce sıklıkla karşılaşma ve çözme deneyimlerine daha fazla sahip olmuştur. Dolayısıyla da kişilerin karakterine ve tarzlarına uygun birtakım yönergeleri zamanla oluşturmuş olabilir. Sadece yakın ilişkilerin bilgisi değil, güzelleşmeye dair tüyolar, aktüalite, siyaset ve eğer mahallede ise mahallede olup bitenlere dair gibi pek çok bilgiler de bu ağdadır. Toplumsal bilginin bu yöndeki kullanımı ve dağıtımı bizi Schütz’ün "gündelik yaşam dünyası" ve "bilgi stoku" kavramlarına götürür: "Gündelik yaşam dünyası", bizim dünyaya gelișimizden önce de var olan ve düzenlenmiş bir dünya olarak bizden önce başkalarınca da yorumlanmış ve deneyimlenmiş olan özneler-arası bir dünyaya işaret eder. Bu dünya, şu 
anki deneyim ve yorumlarımıza kendini sunar. Bu dünyaya ilişkin bütün yorumlamalar, kendisine yönelik geçmiş deneyimlerden ve "el altındakullanıma hazır bilgi" biçiminde bir başvuru şeması olarak işleyen, ailemizden ve eğiticilerden bize miras kalan deneyimlerimizden oluşan bir bilgi stokuna dayanır (Schütz, 2018:85).

Kuaför, ortam ve karşılıklı etkileşimler itibariyle bir yaşam dünyası şeklinde yorumlanabilir. Kuaför çalışanının farklı kadın profilleri tanımasından ve birikmiş deneyimlerinden ortaya çıkan bir bilgi stoku söz konusudur. Kuaför bu bilgiyi hizmetin yan ürünü olarak biriktirir, tasarlar ve yayar.

A24 (25 yaşında):Bilgi aktarımı merkezi gibidir kuaför. Sürekli bir bilgi akışı olur saç tarzı vs. hakkında, bu da medyanın etkisi altındadır. Aslında psikolog yerine kuaföre giden pek çok insan da tanıdım.

A11(25 yaşında/öğretmen):Sevgilisinden ayrılanlar, kocasıyla kavga edenler, çocuğundan şikâyetçi olanlar... Yani her kadın bunları kuaförüyle paylaşıp ondan görüşlerini alır ve değer verir kuaförünün görüşlerine.

Alt ve orta sınıfa hitap eden kuaförlerde bilgi aktarım işlevi daha yoğun şekilde yaşanmaktadır. Tanışıklığın verdiği güven sayesinde paylaşımların karakteri de değişebilmektedir. Orta sınıfa hizmet sunan Öveçler'deki bir kadın kuaför, hemcinslerinin kendisi ile daha yakın iletişim kurduğundan bahsetmektedir:

AKK3 (35 yaşında):Müşterilerimin çoğu ile yıllardır tanışırız. Sorunlarını, dertlerini her şeyini anlatıyorlar. Sirdaş gibi bir şey oluyor.

Sosyalleşme dolayısıyla kuaför, sadece güzelliğin değil, erkeklerin ve erkeklik dünyasının da bir aynası olma işlevini üstlenir. Erkekliğe ilişkin bilgi stokunun bir yedeği veyahut harici hafızasıdır. Dışarıdaki erkekliğin kuaförün süzgecinden damıtılmıș hali gibidir. Erkeklerin dünyasını anlama, kavrama ve aldığı ipuçlarını özel hayatına transfer edip uygun manevralar geliştirmek açısından son derece işlevsel bir niteliği söz konusu olabilmektedir. Kuaförün elde ettiği deneyime dayalı bilgi stoğu en az iki temel kaynaktan beslenir (özellikle de erkek kuaförler için). Birincisi erkek olma hasebiyle sahip olduğu toplumsal bilgidir. İkincisi ise kadın müşterilerin hayatındaki erkeklerin bilgisini taşımasından elde ettikleridir. Kuaför, müşterilerinin anlattıklarını, kendi deneyimlerini ve sosyal çevresinden elde ettiklerini harmanlar, müşterinin artık arka planını da biraz biliyorsa ona göre bir "ayna" tutar; fikirlerini ve önerilerini paylaşır; yorum ve değerlendirmelerde bulunur. Kuaför sadece kuaförlük hizmetinde değil bu konularda da hünerliyse daha çok değerli hale gelmektedir. Kuaför, müşterisini kendisine bağlama gereğinden dolayı da dolayı bu yöndeki niteliği hep geliștirmek durumundadır.

\subsection{Terapi Merkezi ya da Onarım Merkezi Olarak Kuaför}


Güzelleşmek ve sosyalleşmek, kuaförün açık işlevleri olarak karşımıza çıkmakla birlikte bu sürecin gizli işlevleri de bulunabilmektedir. Özgüveni yüksek, mutlu, sorunlardan uzak ya da sorunlarla baş etme stratejisine sahip olanlar için kuaförün göstereceği olumlu işlevler sınırlı olabilmektedir. Araştırmada; kadınların çoğunluğu, güzellik sayesinde özgüvenlerinin yenilendiğini ve dolayısıyla da sosyal alanda kendilerini güçlü hissettiklerini dile getirmiştir. Özgüveni yetersiz veya sorunlarla baş edebilme stratejilerinden yoksun olanlar için kuaför sağaltıcı birtakım psikolojik işlevler gösterebilmektedir. Bazı kadınlar; ev, iş, okul, arkadaşlık ve yakın ilişkiler başta olmak üzere çeşitli boyutlarda yaşamış oldukları sıkıntıları çözemeseler bile bir nebze de olsa bundan kaçışın sığınağı olarak kuaförü görebilmektedirler. Bu etkileșim savunma mekanizması șeklinde de yorumlanabilir. Dolayısıyla kadınların kendilerini mutlu etme sanatlarından biri olabilmektedir. Görüşmelerde terapi işlevine daire yorumlar elde edilmiştir. Kuaför sayesinde, özellikle de saç stili veya rengi dolayısıyla yaşanan "değişim", yani imajın sembolik göstergesindeki değişim, psikolojik ruh halini de etkileyebilmektedir. Dolayısıyla kuaför, "değişimin anahtarı" da olabilmektedir. Değişimde en önemli unsurlar beden, yüz ve saçtır. Fiziksel görünüm nasıl olursa olsun saç, imajı değişimindeki en etkili göstergedir. Keza saç (veya saç modeli), toplumsal statünün sembolü olma açısından da nesnel bir anlama dönüştürülmüş gibidir. Kadının toplumsal konumu değiştikçe saç stilinin de değiștirebildiğini söyleyebiliriz.

A58(25 yaşında):Benim için olmadı nedense ama çok gördüm sevgilisinden ayrlan, morali bozuk olan arkadaşlarımın kuaföre gitmek istediklerini. Saçını tamamen sarıya boyatan kahverengi saçlı bir arkadaşım vardı mesela. Bir yenilik oluyor aslında gerçekten, tipiniz değişiyor etrafınızdakiler fark edince değisşikliği sizinle ilgilenmiş oluyorlar hem kuaförde kafa dağıllyor hem de size gösterilen ilgiler edilen övgülerle kafa dağılmış oluyor.

A3(36yaşında/özel sektör):Birçok kadının psikolojik bir çöküntüden sonra soluğu kuaförde aldığını biliyorum. Bunu modern beyaz yakalı kadının çaresizliği olarak görüyorum.

A9(27yaşında):Kendini daha güzel hissedip daha özgüvenli oluyorsun. $B u$ açılan bir terapi sağllyor olabilir.

A41(31yaşında/öğretmen):Evet görüyor çünkü bunalımda olan bir kadın ilk olarak kuaföre gidip saçımı kestirir ya da boyatır değişiklik yaparak ilgiyi o yöne çekmek ister.

A57(25 yaşında):Kesinlikle terapi işlevi görüyor. Tıpkı alışveriş gibi. Paranızı veriyorsunuz, içinizi döküyorsunuz, güzelleşip çıkıyorsunuz. 
Kuaförün sadece saç modeli veya bakım ile sohbet açısından değil, saça dokunması ${ }^{4}$ bile bazıları için terapi işlevi görebilmektedir:

A23 (35 yaşında/arkeolog): Saçımın okşanması yıkanması ellerin dokunması birilerinin saçınız için koşuşturması... Daha ne olsun.

Kadın müşterilerin kuaförün terapi işleviyle ilgili kendi öznel deneyimlerinden hareketle ortaya koydukları öznel anlamlandırmalar dışında kalan ve bu işlevi önemsiz görenlerin gözündeki nesnel anlamlandırma da bu yöndedir:

A56 (42yaşında): Olmaz mi; sırlar, dedikodular, kadınsal kıskançlıklar, rekabet. Ben bunları izlerken çok eğleniyorum.

Diğer taraftan kuaförün terapi işlevi görmesiyle ilgili olarak görüşmecilerden bazılarının buna şüpheyle yaklaştıklarını da not etmemiz gerekir:

A33 (32 yaşında/akademisyen): Görüyor diyebiliriz belki. Zihni değiştirmek zor ama imajı değiş̧irmek kolay. Geçici yanılsamalı bir iyi hissetme hali yaratıyor olabilir.

Kuaförün terapi işlevi konusunda olumlu yaklaşmayanlardan olan A14 (23 yaşında) şu cevabı vermiştir: "Bilemiyorum, benim için sadece şu; 'kırıklarını aldırmak'". Bu nitelemedeki kanaat olumsuz olsa da, olumlu bakanları anlama noktasında metafor olarak kullanılabilir. Merton'ın (1968) açık ve gizli işlevleriyle düşünecek olursak, açık işlev gerçek saç kırıklarının alınmasıdır. Gizli işlev ise, her sosyal sınıf için farklı olabilmektedir. Sözgelimi üst sınıftaki biri çok fazla sohbet etmese bile saç sadece saç modeli değişikliği ile psikolojik açıdan tazelendiğini, özgüven kazandığını hissedebilmektedir. Orta ve daha çok alt sınıftaki bir müşteri

\footnotetext{
4 Morris'in (1980) "Sevmek Dokunmaktır" adlı eserinde dikkat çektiği üzere; konuşma, görme, koku alma gibi durumlar yakınlaşmayı harekete geçirir ama bunların en önemlisi dokunmaktır, zira dokunmak bedensel temas olarak sevmenin en etkili işaretlerden biridir ki bunun biyolojik bir değeri de vardır. Beden hareketi üzerinden gönderilen anlam yüklü bir davranıștır dokunmak. Dokunmak ya da dokunulmasının yasak olması bu açıdan farklı anlamlar yüklü olabilir. Nitekim dokunmanın yasak ya da tabu görüldügü haller de vardır. Dokunmak aynı zamanda insanın kendi bedensel sınırını da ortaya koyar. Yakınlaşmanın sınırı dokunmakla anlam kazanır. Samimiyetin de ölçüsüdür. Tokalaşmak ya da sarılmak veyahut uzun ya da kısa sarılmak, öpmek vb. davranışlar dokunma hareketinin samimiyet ölçüsüne göre karşılıklı anlam değerini inşa eden, onaylayan ve yeniden üreten kodlar taşırlar. Örneğin Türkiye'de halk arasında tabu olarak da anlam kazanan "atın kuyruğuna, erkeğin bıyığına, kadının saçına dokunulmaz" sözü bir çeşit sosyal sınır ya da mesafe tanımıdır. Elbette bu sosyal açıdan "yabancı" için geçerlidir. Bütün bunlar gündelik hayatın etkileşiminde ve kültürel dünyasında "yakınlaşma" üzerinden yorumlanabilir. Kuaförün saça dokunması mesleki bir hadisedir, duygusal bir yakınlaşma anlamı taşımayabilir, ancak dokunmanın insan üzerindeki fizyolojik terapi işlevinin farklı bir surette ama geçici bir süre gerçekleştiriliyor oluşu bir rahatlama şeklini alabilmektedir.
} 
için de bu durum geçerli olmakla birlikte buna ek olarak yaşadığı sorunları, kuafördeki etkileşimler sayesinde bunu aşabilmektedir. Kendisi psikoloğa gidemiyor olsa da kuaför aynı zamanda "işlevsel alternatif" rolünü üstlenebilmektedir. Dolayısıyla hem saç, hem kalp kırıklıklarını alan kuaför, bazı kadınların mutluluk sanatında ve hayata tutunma becerilerinde önemli roller gösterebilmektedir. Kuaförün kendi tecrübelerinden, farklı kadın hikâyelerinden ve zamanında geliştirmiş olduğu önerilerin başarılı ve başarısız sonuçlarını biriktirir, her gün yeniden bunları tatbik eder, geliştirir, değiştirir, günceller. İnşa ettiği bilgi havuzu veya toplumsal bilgi stoku, giderek daha iyi çözüm önerileri sunmaya doğru evrilebilir. Ancak bu her kuaför için geçerli olmayabilmektedir. Başarılı olanlar ise imaj inşası yanında psikolojik veya başka açllardan "çözüm merkezi" niteliği de kazanabilmektedir.

A19 (28 yaşında/büro çalışanı): Bazı zamanlarda hem bir erkek gözüyle bakabilmesi hem de kadın halinden daha iyi anlaması bakımından kuaförümün verdiği tavsiyeler işe yarıyor, bu bağlamda bana katkı sunuyor.

A21 (23 yaşında/öğrenci): Çözüm sunduğu oluyor. Bana iş bulmuştu.

A57 (25 yaşında): Maddi yönden bu ilişskiler bağlamında sorunlara yol açabilir. Aynı zamanda manevi yönden de etrafına ve kendine bakımlı göründüğü için bu sorunların çözümüne katkı sağlayabilir.

A58 (25 yaşında): Kadınlar gidip orada sorunlarını da anlattıkları için tavsiyeler allyorlar çoğu zaman bu tavsiyelere uyulduğunu söyleyebilirim kadın olarak. Yani kadınlar ortak akılla hareket etmeyi severler. Katkı da olabilir köstek de olabilir. Yani verilen tavsiyelere bağlı. Ama kadınlar o arada gidip içlerini döktükleri için sinirleri yatışmış olabiliyor. Oraya öfkelerini ya da mutsuzluklarını bırakıp daha ferah düşünmeye başlayabilirler.

\subsection{Rekabet Sahası Olarak Kuaför}

Gösteriş piyasasında, bireysel ve toplumsal kimlikler birbirleriyle sürekli rekabet halinde anlam kazanırlar. Rekabet; gösterişin, ilgi görmenin, fark edilmenin ve fark yaratmanın lokomotifi gibidir. Sosyal ilişkileri dinamik kılan işlevi olduğu da şüphesizdir. Kuaförde kadın çalışanın müşterilerce istenmemesi de rekabet eksenli etkileşim çerçevesinde değerlendirilebilir. İmaj üzerine kurulu rekabet, tanışık olsun ya da olmasın bazı davranışlarda bariz görülebilmektedir. Ankara'da ünlü bir AVM'de kuaförlük yapan AK1 (35 yaşında/Çankaya) hem kuaförün gösteriş alanına vurgu yapmakta hem de kadınlar arasındaki rekabete dikkati çekmektedir:

"Bizde müşteriler genelde yalnız gelirler. Arkadaşıyla gelmeyi tercih etmiyorlar. Hani benimle fazla ilgilenmeyecek diye. Onun için arkadaşını gönderecekse sonra gelir.(...) biz ürün de satıyoruz. Birisi ürün aldı diye, 
yandaki göz ucuyla bakar; kıskanır. Cebinde parası yoksa bile kredi karıla bile çektirip alır onu, sırf aynı seviyeye çıkabilmek için. Bahşişte de öyle mesela. Birisi bahşiş vermişse ve görmüşse ve üzerinde parası yoksa mutlaka bulur, gider bankamatikten çeker, bir şekilde bankamatikten telafi edip getirir verir, gösterir. Yani bayanlar arasında biraz da hırsla yürüyor bu iş. Hatta kadınlar arasındaki rekabet en çok bize yarıyor."

Söz konusu kuaförde gerçekleştirilen gözlemlerde ve görüşme yapılan kadın müşterilerden elde edilen bilgilerde bahsedilen rekabetin bütün kadın müşterilere genellenebilir olmadığını da belirtmek gerekir. Rekabet, bazı kadın müșteriler tarafından da vurgulanmaktadır. Keza yukarıdaki kuaför dışında da kadın müşteriler arasında rekabetin olduğunu belirten çalışanlar da olmuştur. ${ }^{5}$ Öte yandan rekabet ilişkisi tüm müşterilerde aleni şekilde görülmeyebilmektedir. Sözgelimi kadın müşterilerden biri bahşişi gizlice ya da kasada verdiğini ifade ederek bu yöndeki rekabet gösterişine girmek istemediğini belirtmiş, ancak kuaföre arkadaşlarıyla birlikte gitmediğini ifade ederek de örtük bir şekilde rekabeti onaylamıştır. Dolayısıyla bütün kadın müșteriler arasında olmasa bile imaj yapılanması sürecinde bir rekabet eğiliminin olduğu söylenebilir.

Kuaföre yalnız gitme eyleminin rekabetin başka bir göstergesi olduğunu ifade edebiliriz. Görüşmecilerin çoğunluğu yalnız gittiğini ifade ederken kuaför çalışanlarının genel gözlemi de kadınların ekseriyetle kuaföre yalnız geldiği yönündedir. Kuaförün niteliğine göre de değişen bu durum "imaj rekabeti”nin yaygın olduğu toplumsal sahalarda daha keskin şekilde yaşanmaktadır. Hatta gittiği kuaförden son derece memnun olanların bazen bunu çevresiyle paylaşmadığını da söyleyebiliriz. Bütün bunların imaj ve gösteriş noktasında ciddi rekabet kaynaklarıdır. Bir görüşmecinin şu gözlemi de önemlidir:

A13 (25 yaşında/öğrenci): Genelde gözlemlediğim, genelde dertleșmeye, evdeki sorunlardan uzaklaşmaya, kafa dinlemeye geliyorlar. Kuaför ortamı kadına sosyalleșme imkânı sunarken rekabeti de körükleyebiliyor.

Rekabet, güzellik ve imaj hususunda kadınlar arasındaki etkileşimi arttırmaktadır. Bir yönüyle aralarındaki mesafeyi azaltabilmekte, başka yönüyle de mesafeyi arttırabilmektedir, yani çift yönlüdür. İlgi odağı olmak, diğerlerinden farklı olduğunu hissetmek ve buna bağlı olarak özgüveni yüksek ve mutlu duygular beslemek imaj dolayısıyla olduğu için imaj bir rekabet unsuruna dönüşmekte; nihayetinde piyasalaşan/metalaşan bir hüviyete bürünebilmektedir. Diğer taraftan rekabetin kadınları dinamik

\footnotetext{
5 Ankara-Öncebeci Mahallesi'nde kuaför salonları üzerine araştırmada bulunan Şenel (2017), kadınların "kıskanç ve birbirini çekemez" şeklinde kodlanmasının daha çok erkek çalışanlar tarafından vurgulandığını aktarmıştır.
} 
kıldığını, bu dinamizmin aynı zamanda güç ilişkilerine dayandığını ifade edebiliriz.

Goffman (2009), sosyal hayatı "sahne" metaforuyla çözümlediği analizinde sahne önündeki davranışların performanslarına ve bu performansların bireyin sosyal benliğindeki örüntülerine dikkati çekmiștir. Kuaförler de gösteriş piyasasının imajlar üzerinden rekabetin yaşandığ sahnelerdir ve bu sahnelerdeki performans yarışı, "imaj rekabeti"dir esasında. Modern zamanın karakteristik/köșeli davranış biçimleri, güzellik imajları ve bu imajların karşılık geldiği belirgin sosyal sınıflar yerine daha melez ilişki formları ortaya çıkmaktadır. "21. yüzyıl toplumu artık bir disiplin toplumu değil, performans toplumudur. Sakinleri de "itaatkâr özne" değil, performans öznesidir. $\mathrm{Bu}$ özneler kendi kendilerinin müteșebbisleridir." diyen Han'dan (2015: 17) hareketle kuaföre gitmenin günümüz performans toplumunun öznesi olmayı ve imaj sahibi olmanın da kendi kendinin imaj müteşebbisi olmayı gerekli kıldığını söyleyebiliriz. 1930'larda yaygınlık kazanan "Çirkin kadın yoktur; kendine bakmayan kadın vardır" anlayışıyla başlayan güzellik demokrasisi; gerilim, yarışma, rekabet ve kimi zaman sertlik, çileci psikolojik uzamda vücuda gelen iradeye seslenerek (Vigarello, 2013: 228-237) bugüne uzanmış, gösteriş piyasasını var etmiştir. Artık, kendine bakmak, bakımlı olmak, dönemin güzellik imajına uygun yol almak, bir irade işi olarak kodlanmaktadır ve bu iradeler savaşı bugünün dünyasında tüketilen güzelliğin lokomotifleri arasında konumlanmaktadır.

\section{Güç Kaynağı Olarak İmaj}

Toplumsal cinsiyet eşitsizliği bağlamında imaj yapılandırma süreci olumlu işlevler de, olumsuz işlevler de üstlenebilmektedir. Kadınlar açısından en olumlu işlev, kendilerini daha fazla özgüvenle algılamalarıdır. Dolayısıyla imaj veya güzellik, sosyal etkileşimler sahasında kadınlar için bir güç kaynağı olabilmektedir. Ataerkilliğe, piyasa ilişkilerine, sınıfsal ve eşitsiz koşullarda inşa olunan beğeni biçimlerine rağmen kadınlar, özellikle de karşı cinsle ilişkilerinde göreli bir imaj gücü taşıyabilmektedirler.

A27 (26 yașinda/halkla ilişkiler): Insan kendini güzel hissettiği her zaman, özgüveni de artar dolayısıyla güçlü de hisseder. Bunu yaptığı bakım sağlıyorsa güçlü kıldığını söyleyebilirim. Güzellik, kadının bilgili olması dışında ona değer katan diğer unsurdur.

A57 (25 yaşında): İmajınız biriyle tanıştı̆̆ınızda, bir işe başvurduğunuzda, aynada kendinize baktığınız anda "her şey" demektir, buna rağmen yüzeysel bir şey olduğunu da unutmamak gerekir. Kuaförlerin güzellik imajındaki rolü belirleyicidir. Saçlarımız, görünüşümüzü en çok değiştiren bölümdür.

İmajın kadını güçlü kıldığına dair görüşe itirazlar da söz konusudur: 
A36 (32 yaşında/akademisyen): Özgüven verebilir ancak güçlü kılmaz. Kadının gücü bağımsız kişilik geliştirmiş olması ile ilgili bence. Güzellik bir silah olabilir ancak kadın zaten güçlü ise. Cok güzel ama kendini geliştirmemiş kadınlar var. İki konusunca güzelliği kayboluveriyor.

Güzelliğin ve imajın kadınları güçlü kılmasının geleneksel toplumsal cinsiyet rolleri açısından da anlamları bulunmaktadır. Kadının imajdan dolayı güçlenmesi ve kendini güçlü hissetmesi, özel ve kamusal alandaki performansını doğrudan etkileyen ve elbette ki yeterli sayılmayacak bir durum olsa da, başka güç kaynaklarına erişme noktasında ve eşitsiz toplumsal ilişkileri ile cinsiyet rollerini aşabilme noktasında kolaylaştırıcı bir enerji imkânı sunabilmektedir. Ancak imaj hususunda, kadınlar arasındaki güç ve rekabet de olumsuz bir işlev olarak kadınların aleyhine olabilmektedir. Goffman'ın (2009) benliğin sunumunda dillendirdiği performans yaklaşımından hareketle, kadınlar bağlamında, güzellik ve güç ilişkisine dair "ne kadar bakış, o kadar alkış" ifadesini kullanabiliriz. Kadın ne kadar dikkat çekerse hem erkekler alanının vektöründe hem de kadınlar alanındaki rekabet sahnesinde bir adım öne çıtığını hissetmektedir. Buradaki özgüven, başka alanlara ve başkalarına yönlendirildiğinde güce dönüşebilir, performansı daha da arttırabilir. Schütz'ün (2018:187, 211) işaret etmiş olduğu; bireylerin karşılıklı-özne ilişkisiyle birbirine yöneldiği "iletişimsel ortak çevre" içinde gerek doğrudan iletişimin olduğu "sen yönelimlilik"te ve gerekse doğrudan etkileşimlerinin olmadığı mefhumlara dair "onlar yönelimlilik"te (252-253) kadınların sahip olduğu bu güç nesnel anlama kavuşabilmektedir.

\section{Sonuç: Güzellik Sosyalleşmesinden Güzellik Sözleşmesine}

Gündelik hayatın vazgeçilmezlerinden biri haline dönüşen kuaföre gitme pratiği; kullanım amaçları ve işlevleri ekseninde çeşitli boyutlara sahiptir. Toplumsal sınıflar bağlamında baktığımızda kuafördeki imaj yapılandırılışı, üst sınıf ile bazı orta sınıf müşteriler için açık işleviyle sınırlı, sadece araçsal olarak tercih edilirken alt sınıflara doğru gidildikçe sosyalleşmek gibi örtük işlevler de devreye girmektedir. Aralarında belirgin bir ayırım olmasa da işlevler açısından her katmanda açık veya gizli; olumlu veya olumsuz işlevlerin söz konusu olduğunu görmekteyiz. Diğer taraftan imaj, toplumsal cinsiyet eşitsizliğinde kadınlara güç kaynağı olabildiği gibi aralarındaki rekabet konusundan dolayı bu eşitsizliği kadın aleyhine yeniden üretebilmesinin gerekçesi de olabilmektedir.

İmaj, benlik vitrinlerinde, gösteriş piyasasında en önemli rekabet araçlarından biri olmaktadır. Kuaför ise imaj rekabetini tesis etme hususunda işlevler gösteren "imaj yaratıcısı" veya kimileri için de "imaj yardımcısı" rolündedir. Rekabetin sermayesi olan imaj; sürekli kendini yenileyerek var etme eğilimindedir. Yenilik ve farklılık; özel davranış biçimleri olarak anlamlandırılabilmekte ve birbirinden farklılaşmanın kodu 
halinde yorumlanabilmektedir. Başkalarının aynasında farklı imajla görünme arzusuna dayalı tüketim ilişkisi, son kertede herkesin farklı olmak isterken aynı davrandığı benzerlik formunu ortaya çıkarmaktadır. Herkesin farklılık adına benzer davranışları sergilediği yerde esasında biçimsel bir aynılığın tesis edilmesi anlamına geldiğini söyleyebiliriz. Kuaförde her ne kadar farklı bir imaja sahip olacak şekilde hizmet beklenilse de nihayetinde herkesin aynı amacı benzer bir davranış biçimini bize göstermektedir. Dolayısıyla çeşitlilik ve farklılık belirli kültürel davranış kalıplarında bir biçime dönüşmektedir. Sonuç olarak farklılıklar aramanın biçimsel benzerliği Habermas'ın (2001) "yaşama evreninin sömürgeleştirilmesi" şeklinde tanımladığı olguya işarettir. Habermas'ın göreli yüksek bir genelleme aşamasında tarif etmeye çalıştı̆̆ yaşama evreninin sömürgeleştirilmesinin daha düşük seviyedeki göreli eğilimi bugünün imaj yapılanışında da görmekteyiz. Farklı imajlarla benlik inşasını zorlamayan yapısal süreç, dışarıdan içeriye doğru görünüşte farklı ancak biçimsel açıdan benzeșen ve sömürgeleştirilmekte olan bir gündelik hayat pratiğini karşımıza çıkarmaktadır. İmaj yapılandırılmasında bireyler pasif değildirler, birçoğu bu sürecin farkındadır; yaratıcı ve dönüştürücü hamleler de yapabilmektedirler. Ortaya çıkan nesnel biçimsel benzerlik güzelleşme ve imaj üretimine odaklı, tüketim ilişkileri ile örülü geniş bir "güzellik sosyalleşmesi"dir. Güzellik sosyalleşmesinin sosyalleşmenin giderek zorunlu bir davranışa dönüşmesi yanında kitle kültürü bağlamında mekânda ve zamanda genişleyen bir niteliği de bulunmaktadır. İmaj üretiminde kuaförlerin işlevi değiştiği gibi kadınların kendi kendilerinin imaj yaratıcı olma ama bu imaj yaratımını da yine bașta internet olmak üzere yeni etkileşim ve iletişimsel eylem çevrelerinden elde etme eğilimleri bizi, güzelliğin sosyolojik karakterinde "güzellik sözleşmesi"ne götürmektedir. Piyasa ilişkileri içine gömülü olan, içinde rekabeti, çatışmayı ve dinamizmi de barındıran, eleştirel baksa bile bu tür pratiklerden de geri kalamayan, zamanından ve başka türlü yaşam pratiklerinden feragat ederek bu etkileşime dâhil olan aktörlerin ortak rızasıyla inşa edilen yeni bir güzellik sözleşmesidir bu. Güzellik sözleşmesi aynı zamanda, açık ya da örtük șekilde cereyan eden önemli bir sosyal kontrol ve yönlendirme mekanizmasıdır da. Bu sözleşme, rekabet, göz kontrolü, tüketim ilişkileri, güç ilişkileri, sembolik sermaye mücadeleleri açısından son derece karmaşıktır ve ayrıca imaj üzerinden benliklerin inşa edildiği dinamik etkileşimler bileşkesine dayalıdır.

\section{KAYNAKÇA}

ADORNO, Theodor W. (2007). Kültür Endüstrisi Kültür Yönetimi. (Çev.: Elçin Gen, Nihat Ülner, Mustafa Tüzel), 2. Baskı, İstanbul: İletişim Yayınları.

ATAY, Tayfun (2017). Görünüyorum O Halde Varım /“Meşhuriyet Çağı”nda Kültür ve Insan. İstanbul: Can Yayınları. 
BOURDIEU, Pierre (2015). Ayrım: Beğeni Yargısının Toplumsal Eleștirisi. (Türkçe Söyleyenler: Derya Fırat Şannan, A. Günce Berkkurt), Ankara: Heretik Yayınları.

CRESWELL, John W. (2013). Nitel Araștırma Yöntemleri-Beș Yaklașıma Göre Nitel Araştırma ve Araştırma Deseni. (Ed. Çev.: Mesut Bütün, Selçuk Beşir Demir), Ankara: Siyasal Kitap Yayınları.

DEBORD, Guy (2006). Gösteri Toplumu ve Yorumlar. (Çev.:Ayșen Ekmekçi, Okşan Taşkent), 2. Baskı, İstanbul: Ayrıntı Yayınları.

ELIAS, Norbert (2013). Uygarlık Süreci-I. (Çev.: Ender Ateşman), 7. Baskı, İstanbul: İletişim Yayınları.

FERRY, Luc (2012). Homo Esteticus: Demokrasi Çağında Beğeninin İcadı. (Çev.: Devrim Çetinkasap), İstanbul: Pinhan Yayınları.

GIDDENS, Anthony (1999). Toplumun Kuruluşu: Yapılaşma Kuramının Ana Hatları. (Çev.: Hüseyin Özel), Ankara: Bilim ve Sanat Yayınları.

GÜRBİLEK, Nurdan (2016). Vitrinde Yaşamak: 1980’lerin Kültürel İklimi. 8. Baskl, İstanbul: Metis Yayınları.

GOFFMAN, Erving (2009). Günlük Yaşamda Benliğin Sunumu. (Çev.: Barış Cezar), İstanbul: Metis Yayınları.

HABERMAS, Jürgen (2001). Illetişimsel Eylem Kuramı. (Çev.: Mustafa Tüzel), İstanbul: Kabalcı Yayınları.

HAN, Byung-Chul (2015). Yorgunluk Toplumu. (Çev.: Selim Yalçın), İstanbul: Açılım Yayınları.

KOZANOĞLU, Can (2001). 1980'lerden 90'lara Türkiye ve Starları: Cilalı Imaj Devri. İstanbul: İletișim Yayınları.

MERTON, Robert K. (1968). Theory and Social Structure. (Enlarged Edition), New York: The Free Press.

MORRIS, Desmond (1980). Sevmek Dokunmaktır. (Çev.: Engn Darıca). 2. Baskı, İstanbul: Sander Yayınları.

SCHUTZ, Alfred (2018). Fenomenoloji ve Toplumsal İlişkiler. (Türkçe Söyleyenler: Adnan Akan, Seyda Kesikoğlu), Ankara: Heretik Yayınları.

SIMMEL, Georg (2009). Bireysellik ve Kültür. (Çev.: Tuncay Birkan), İstanbul: Metis Yayınları.

ŞENEL, Burcu (2017). "İçeriden Dışarıya, Dünden Bugüne: Mahalleye Açılan Kapı Olarak Kuaför Salonu”. Aynanın Önünde Cımbızın Ucunda: Kuaför Kitabı, (Der.: F. Şenol Cantek), s.111-145, İstanbul: İletişim Yayınları.

ÜSTÜNER, Tuba ve THOMPSON, Craig J. (2012). "How Marketplace Performance Produce İnterdependent Status Games and Contested Forms of Symbolic Capital". Journal of Consumer Research, Vol.38, pp.796-814.

WILLIAMS, Raymond (1961). The Long Revolution. London: Chatto And Windus.

VIGARELLO, Georges (2013). Güzelliğin Tarihi; Rönesans'tan Günümüze Beden ve Güzelleşme Sanatı. (Çev.: Erkan Ataçay), Ankara: Dost Yayınları.

YUMUL, Arus (2004). "Kadın Kuaförlerinin Gündelik Hayattaki Yeri: İstanbul Örneği”. Saç Kitabı, (Ed.: Emine Gürsoy Naskali), s. 165-174, İstanbul: Kitabevi Yayınları. 